\title{
Investigation of the bonding strength and bonding mechanisms of SOFCs interconnector-electrode interfaces
}

Boccaccini, Dino N.; Sevecek, O. ; Frandsen, Henrik Lund; Dlouhy, I. ; Molin, Sebastian; Cannio, M.; Hjelm, Johan; Hendriksen, Peter Vang

Published in:

Materials Letters

Link to article, DOI:

10.1016/j.matlet.2015.07.137

Publication date:

2016

Document Version

Peer reviewed version

Link back to DTU Orbit

Citation $(A P A)$ :

Boccaccini, D. N., Sevecek, O., Frandsen, H. L., Dlouhy, I., Molin, S., Cannio, M., Hjelm, J., \& Hendriksen, P. V. (2016). Investigation of the bonding strength and bonding mechanisms of SOFCs interconnector-electrode interfaces. Materials Letters, 162, 250-253. https://doi.org/10.1016/j.matlet.2015.07.137

\section{General rights}

Copyright and moral rights for the publications made accessible in the public portal are retained by the authors and/or other copyright owners and it is a condition of accessing publications that users recognise and abide by the legal requirements associated with these rights.

- Users may download and print one copy of any publication from the public portal for the purpose of private study or research.

- You may not further distribute the material or use it for any profit-making activity or commercial gain

- You may freely distribute the URL identifying the publication in the public portal 


\section{Author's Accepted Manuscript}

Investigation of the bonding strength and bonding mechanisms of SOFCs interconnector-electrode interfaces

D.N. Boccaccini, O. Sevecek, H.L. Frandsen, I. Dlouhy, S. Molin, M. Cannio, J. Hjelm, P.V. Hendriksen

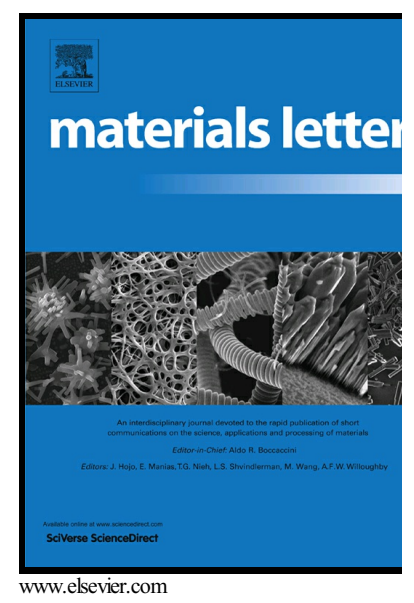

PII: $\quad$ S0167-577X(15)30329-3

DOI: $\quad$ http://dx.doi.org/10.1016/j.matlet.2015.07.137

Reference: MLBLUE19335

To appear in: Materials Letters

Received date: 13 July 2015

Accepted date: 26 July 2015

Cite this article as: D.N. Boccaccini, O. Sevecek, H.L. Frandsen, I. Dlouhy, S Molin, M. Cannio, J. Hjelm and P.V. Hendriksen, Investigation of the bondin€ strength and bonding mechanisms of SOFCs interconnector-electrode interfaces Materials Letters, http://dx.doi.org/10.1016/j.matlet.2015.07.137

This is a PDF file of an unedited manuscript that has been accepted fo publication. As a service to our customers we are providing this early version o the manuscript. The manuscript will undergo copyediting, typesetting, an review of the resulting galley proof before it is published in its final citable form Please note that during the production process errors may be discovered whic could affect the content, and all legal disclaimers that apply to the journal pertain 


\title{
ACCEPTED MANUSCRIPT
}

Investigation of the bonding strength and bonding mechanisms of SOFCs interconnector-electrode interfaces

D. N. Boccaccini ${ }^{1}$, O. Sevecek ${ }^{2}$, H. L. Frandsen ${ }^{1}$, I. Dlouhy ${ }^{3}$, S. Molin ${ }^{1}$, M. Cannio ${ }^{4}$, J. Hjelm ${ }^{1}$, P. V. Hendriksen ${ }^{1}$

${ }^{1}$ Department of Energy Conversion and Storage, Technical University of Denmark,

Frederiksborgvej 399, DK-4000 Roskilde, Denmark

Tel: +45 467746774730 , Fax: +45 4677 5858, E-mail: dinb@dtu.dk

${ }^{2}$ Brno University of Technology, Institute of Solid Mechanics, Mechatronics and Biomechanics, Technická 2, 61669

Brno, Czech Republic

${ }^{3}$ Institute of Physics of Materials, Academy of Sciences of the Czech Republic, Zizkova 22, 61662 Brno, Czech

Republic

${ }^{4}$ University of Modena and Reggio Emilia, Department of Engineering “Enzo Ferrari”, Modena 42025, Italy

\begin{abstract}
The determination of the bonding strength (BS) between solid oxide cell (SOC) electrodes and metal interconnects (IC) is of importance since it can impact the SOC lifetime. There are several methods for determining the adhesion between ceramic and metal layers at the macro-scale level, but no standard technique for such measurement is available. In this work, the BSs between an anode support (AS) and three different cathodes with a SOC interconnect were tested in three point bending test configuration. An adaptation of the Schwickerath crack initiation test (SCIT) (ISO 9693) was used to verify its applicability for the determination of bonding strength in the interfaces. The results suggest that this test is a valid method for the mechanical characterization of SOC interfaces.
\end{abstract}

Keywords: Schwickerath crack-initiation test, three-point bending test, SOC interfaces, metal-ceramic bond strength

\section{Introduction}

The bonding between SOC electrodes and metal ICs is a critical issue, which may determine the stack lifetime[1]. An understanding of the bonding mechanism is essential to design successful ICcathode/anode interfaces in SOCs. Metal-ceramic bonds, which occur during the ceramic firing, have been classified into three main categories: chemical bonding, mechanical interlocking and Van der Waals forces[2].

Although it is of importance to measure the interfacial crack resistance of a SOC[3,4], no standard technique for such measurements is available. Therefore, the objective of the present investigation is to explore the feasibility of utilizing the SCIT (ISO 9693), introduced in 1999 for dental ceramicmetal composites[5,6], for the determination of SOCs IC-cathode/anode BS. Despite the different 


\section{ACCEPTED MANUSCRIPT}

material properties and geometries used in SOCs, the ceramic-metal bonding mechanisms are similar and then the evaluation of the bonding strength could be performed similarly. In this work the method is revised to deduce the contribution from the residual stresses (RS) on the strength separately, as the RS vary with temperature and time.

\section{Experimental}

Four different interfaces are investigated in this work: A) IC-LSM cathode contact layer with LSCF:CGO cathode, B) IC-LSC:CGO cathode; C) IC-LSCF:CGO cathode and D) inteconnect3YSZ-Ni AS. Table 1 lists the main properties of the layers and materials on either side of the interface, while methods employed for their characterization and literature are reported elsewhere[7].

\begin{tabular}{|c|c|c|c|c|c|c|}
\hline Layer name & Material & $\begin{array}{c}\text { Thickness } \\
(\mu \mathrm{m})\end{array}$ & Porosity & $\begin{array}{c}\text { TEC } \\
\left(\text { Averaged 25-900 }{ }^{\circ} \mathrm{C}\right) \\
\left(10^{-6} / \mathrm{K}\right) \\
\end{array}$ & $\begin{array}{c}\mathbf{E} \\
(\mathrm{GPa})\end{array}$ & $\begin{array}{c}\text { Layers } \\
\text { contained in } \\
\text { configurations } \\
\end{array}$ \\
\hline $\mathbf{A S}$ & $3 \mathrm{YSZ} / \mathrm{NiO}$ & 290 & 0.11 & 13.1 & $157 \pm 30$ & $\mathrm{~A}, \mathrm{~B}, \mathrm{C}$ \\
\hline Anode & $8 \mathrm{YSZ} / \mathrm{NiO}$ & $\begin{array}{c}12.5(10- \\
15)\end{array}$ & 0.05 & 12.6 & $183 \pm 20$ & $\mathrm{~A}, \mathrm{~B}, \mathrm{C}$ \\
\hline Reduced AS & 3YSZ/Ni & 290 & 0.35 & 12.9 & $96 \pm 42$ & $\mathrm{D}$ \\
\hline Reduced anode & 8YSZ/Ni & $\begin{array}{c}12.5(10- \\
15)\end{array}$ & $0.27 *$ & 12.5 & $\begin{array}{c}100 \pm 30 \\
*\end{array}$ & $\mathrm{D}$ \\
\hline Electrolyte & 8YSZ & $10(9-12)$ & 0 & 10.8 & $201 \pm 14$ & $\mathrm{~A}, \mathrm{~B}, \mathrm{C}, \mathrm{D}$ \\
\hline CGO layer & CGO & $5.5(3-8)$ & 0.20 & 12.5 & $106 \pm 25$ & A,B,C \\
\hline Cathode & LSCF:CGO & $15-20$ & 0.31 & 13.95 & $61 \pm 27$ & $\mathrm{~A}, \mathrm{C}$ \\
\hline Cathode & LSC:CGO & $15-20$ & 0.38 & 18.75 & $44 \pm 17$ & B \\
\hline Cathode contact layer & LSM & 50 & 0.22 & 12.3 & $65 \pm 19$ & A \\
\hline IC Co layer & $\mathrm{Co}_{3} \mathrm{O}_{4}$ & 2.5 & - & 9 & $152 \pm 19$ & $\mathrm{~A}, \mathrm{~B}, \mathrm{C}$ \\
\hline IC Co reduced layer & Co & 2 & - & 13 & $207 \pm 20$ & D \\
\hline IC spinel layer & $(\mathrm{Mn}, \mathrm{Cr})_{3} \mathrm{O} 4$ & 2 & - & 9 & $201 \pm 13$ & $\mathrm{~A}, \mathrm{~B}, \mathrm{C}, \mathrm{D}$ \\
\hline IC metal & $\begin{array}{c}\mathrm{Fe} \mathrm{Cr} \text { stainless } \\
\text { steel }\end{array}$ & 300 & - & 12.3 & $200 \pm 14$ & $\mathrm{~A}, \mathrm{~B}, \mathrm{C}, \mathrm{D}$ \\
\hline
\end{tabular}

\section{Materials}

SOC cells were prepared and laser cut to the final dimension of $(8 \pm 0.1) \mathrm{mm} \times(3 \pm 0.1) \mathrm{mm}$ to measure the BS by the SCIT. The average thickness of the cells after the cathode deposition was $(0.4 \pm 0.01) \mathrm{mm}$. Commercially available ICs (Crofer 22 APU ®) for SOFC with a thickness of $(0.3 \pm$ $0.01) \mathrm{mm}$ were cut to dimensions $(15 \pm 0.1) \mathrm{mm} \times(3 \pm 0.1) \mathrm{mm}$ and assembled with the laser cut cells following the geometric configuration of the standard ISO 9693 as shown in Fig. 1.

\section{Sintering}

The specimens were fired at $930^{\circ} \mathrm{C}$ for $24 \mathrm{hrs}$ with heating and cooling rates of $2^{\circ} \mathrm{C} / \mathrm{min}$. Loads $\left(0.5 \mathrm{~kg} / \mathrm{cm}^{2}\right)$ were applied outside the furnace and transmitted to the sample by an alumina rod to simulate the real compressive stresses in the stack. In the case of the anode-IC interface, the firing 


\section{ACCEPTED MANUSCRIPT}

was performed under reducing conditions $\left(9 \% \mathrm{H}_{2}-\mathrm{N}_{2}\right)$. The number of specimens prepared and tested was 15 for each type of interface investigated.

\section{Three point bending test based on the ISO 9693 standard}

A thermo-mechanical analyser (TMA) (TMA 402 F1 Hyperion) was used to perform the SCIT required for the determination of the BS. Fig. 1 shows the sample geometry and the test conditions scheme. The specimens were placed with the ceramic layer facing down in the bending apparatus. The sample was supported by rods $10 \mathrm{~mm}$ apart. The load is applied in the centre with aø2 $\mathrm{mm}$ rod displaced by a piston loading the sample with a rate of $0.025 \mathrm{~N} / \mathrm{min}$. In order to accomplish with the standard requirement, the value of the ratio $\left|\sigma_{\mathrm{xy}}\right| / \sigma_{\mathrm{yy}} \cong 1$ must be verified under pure mechanical loading. Then the bonding strength $(\tau)(\mathrm{MPa})$ is defined as the average value of $\left|\sigma_{x y}\right|$ for a load of $1 \mathrm{~N}$ in the region of positive stress $\sigma_{\mathrm{yy}}$ multiplied by $\mathrm{F}_{\text {fail }}[5,6]$.

$$
\tau=\tau_{\text {res }}+\tau_{\text {ext }}
$$

where $\tau_{\text {ext }}=\sigma_{x y} \frac{F_{\text {fail }}}{F_{F E M}}$ and $F_{F E M}=1 \mathrm{~N}$.

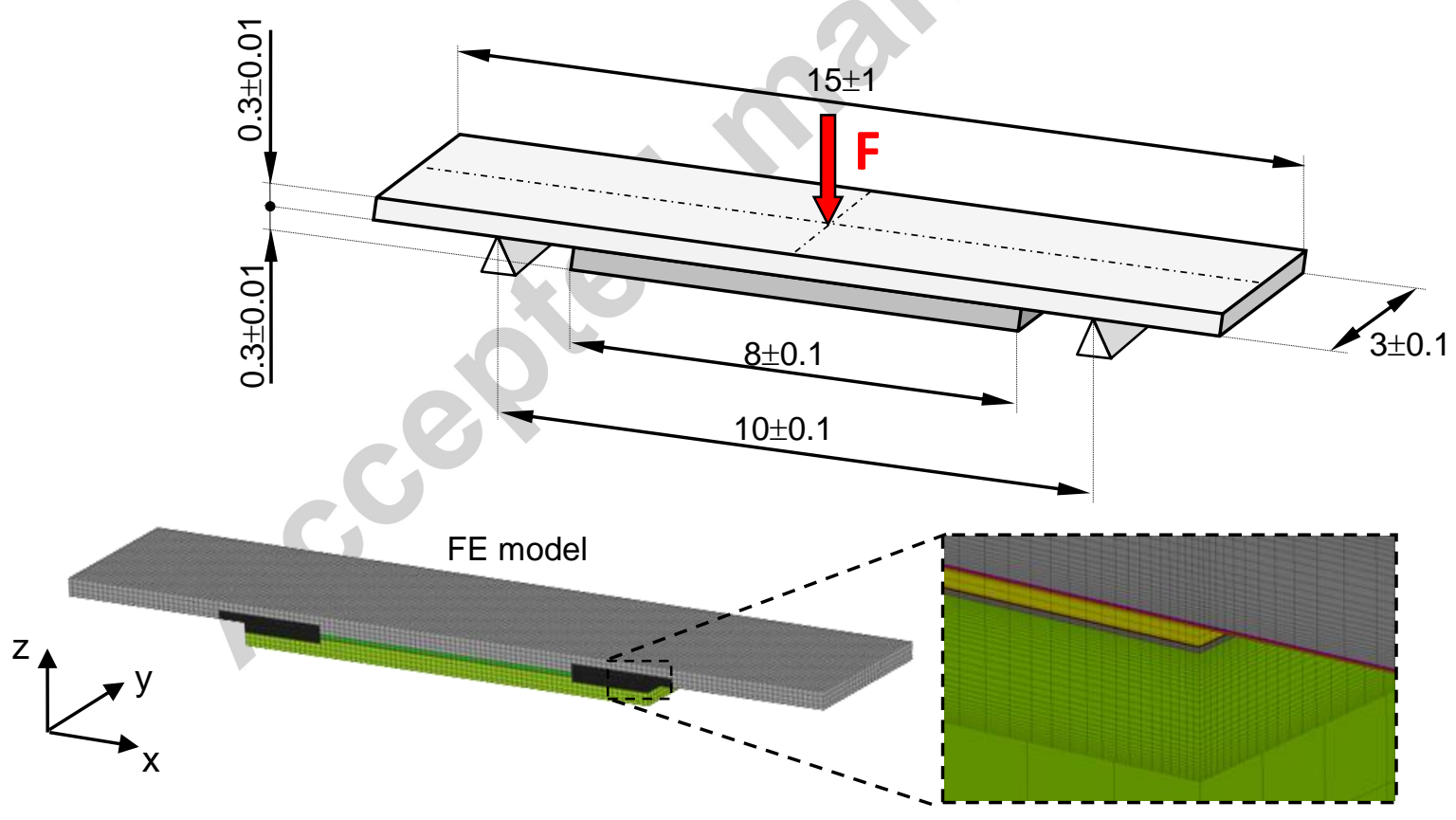

Fig. 1: Test specimen (FE model) configuration (adapted from ISO9693)

\section{Results and discussion}




\section{ACCEPTED MANUSCRIPT}

Fig. 2shows the variation of the load and deflection as function of time for representative samples during the $3 \mathrm{~PB}$ test. Debonding occurs when there is a sudden drop in the displacement and afterwards the displacement rate follows that of the metal alone.

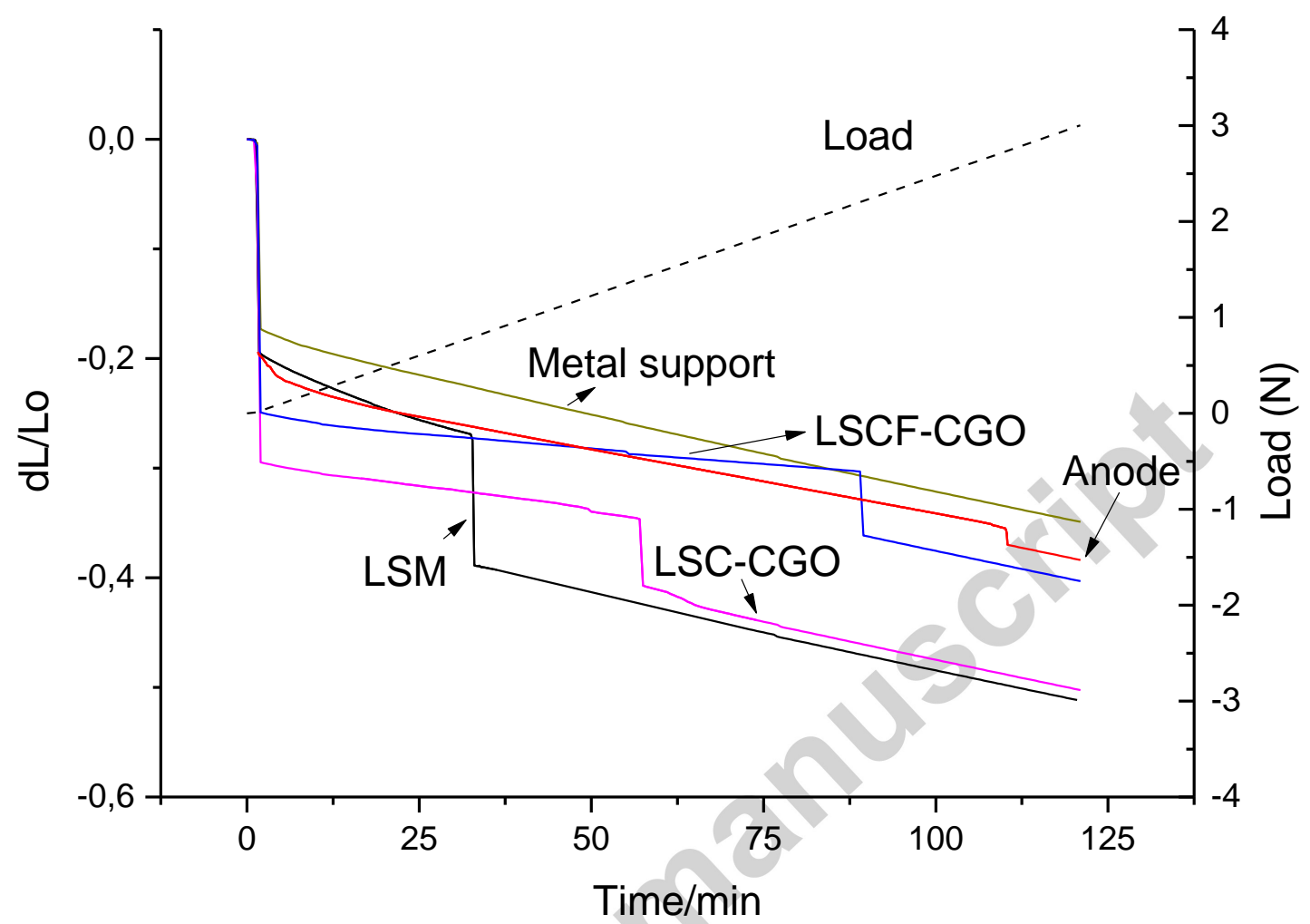

Fig. 2: Load and deflection curves vs. time of representative 3PB tests

Finite Element (FE) analysis was used for the calculations of the RS. The FE model of the specimen (see Fig. 1) is initially loaded by change of the temperature from bonding temperature $\left(930^{\circ} \mathrm{C}\right)$ to the testing temperature $\left(20^{\circ} \mathrm{C}\right)$ (introducing RS) and subsequently subjected to the effects of the actual loading at failure and then insert in eq. 1 to determine the BS. This analysis enables examination of the stress conditions near the edge of the bimaterial notch, where debonding of ceramic and metal usually starts.

The obtained BSs are reported in Fig. 3a-c) together with the $\left|\sigma_{x y}\right| / \sigma_{y y}$ ratios. Fig. 3a) shows that the RS in the anode are low due to good matching of TEC between AS and metal. In case of pure external mechanical loading, the anode can withstand higher load than the cathodes, because it is almost free of thermal stress. However, after the corrections of RS (combined loading), the actual bonding of the anode is lower than that of cathodes. The $\left|\sigma_{\mathrm{xy}}\right| / \sigma_{\mathrm{yy}}$ ratios for pure external mechanical loading are $\cong 1$ for all the interfaces, which is a requirement of ISO 9693-1. 


\section{ACCEPTED MANUSCRIPT}

Fig. 4 shows fresh fracture surfaces on selected samples looking at the metal side. The white spots in the SEM pictures correspond to pieces of cathode material that remained bonded to the metal. A strong mechanical interlocking bonding was identified in the cathodes by nano-indentation testing and Scanning Probe Microscopy (SPM) imaging [7], e.g. LSM particles remained embedded into the scale layer during sintering, giving rise to mechanical interlocking.

Fig. 4 shows the high amount of bonded contact points between cathode and metal in LSC:CGO (the material showing the highest BS) and LSCF:CGO. Fig. 4 indicates a high uniformity of these bonding contact areas in LSC:CGO and LSCF:CGO. The amount of contact areas is strongly dependent on the surface flatness of the electrodes, which is related to the cathode layer deposition method.

Fig. 4 also shows that the debonding crack in the case of the cathode with the LSM cathode contact layer, which is the interface showing the lowest values of BS, has kinked to the cathode contact layer and propagated through it during almost all the debonding process (i.e. the fracture toughness of the cathode contact layer is lower than the interfacial toughness). This explains the fact that the LSM-IC interface shows the lowest standard deviation of all the investigated samples, since the BS is mostly related to the cathode contact layer fracture toughness.

In the case of the anode-IC interface, the bonding mechanisms are based mostly in chemical bonding. The fracture toughness of the anode material (Ni-3YSZ) is higher than the interfacial toughness between anode and IC, and hence the fracture energy is employed to break the bonds between metallic phase of the anode, $\mathrm{Ni}$, (from the reduced anode cermet) and IC. It is important to note that the sintering step used in the sample preparation was performed under reducing conditions $\left(9 \% \mathrm{H}_{2} / \mathrm{N}_{2}\right)$ and hence, both $\mathrm{Co}$ and $\mathrm{Ni}$ remain in the metallic state. The crack propagates through the interface and no crack kinks to the anode cermet were found.

The advantage of this test method is that high reproducibility can be achieved and thus it would serve well for qualitative tests and quantitative comparison of samples with the same approximate dimensions. Note that the high failure stresses achieved by this method cannot necessarily be reached in actual application of the interfaces, as this depends on the geometry of the sample. For design purposes the authors advice a fracture mechanical analysis.

\section{Conclusions}

The Schwickerath test was adapted to account for RS and experiments on solid oxide fuel cell interfaces was carried out in a thermo-mechanical analyser. The small deviation between repeated 


\section{ACCEPTED MANUSCRIPT}

experiments suggest that this test could be a suitable technique for the determination of the BS in SOC's metal-ceramic interfaces. The effect of RS was considered in the analysis, and it was found that they affect the BS significantly. Three different cathode-IC interfaces and one AS-IC interface were characterized.

In the case of the cathode-IC interface, cracks kink through the cathode side while in the case of AS the crack propagates in the interface. The fracture in the cathode IC specimen occurred through the cathode, indicating that the interfacial fracture toughness between cathode and IC seems to be higher than the fracture toughness of the cathode.

After the corrections for RS, all cathode interfaces show high BSs, particularly due to the presence of a strong mechanical interlocking mechanism. On the other side of the cell, the AS has relatively high fracture toughness and as a consequence the crack propagates through the interface. The ASIC interface showed the highest BS of all the investigated interfaces for pure mechanical loading and this can be due a good TEC matching with the metal (low thermal stresses) and the high fracture toughness of AS, making the crack propagate through the interface.

Considering the relevance of the results and reproducibility of the test, it is here proposed that the test methodology could be used to distinguish the different bonding systems in terms of quality and also for a reliable assessment of the BS in SOC interfaces.

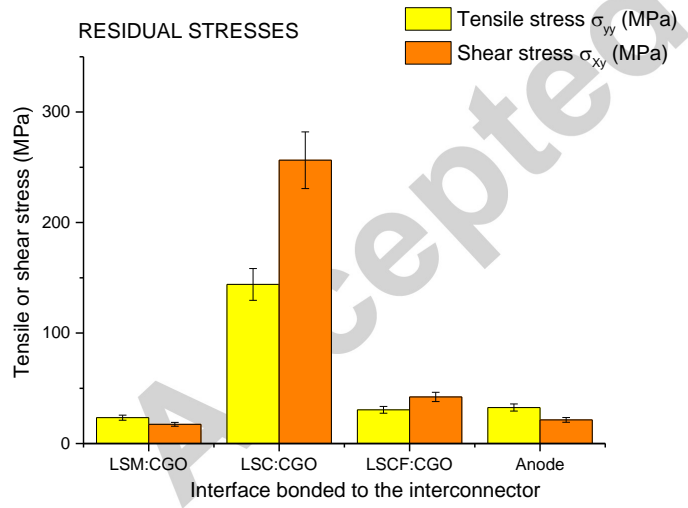

a)

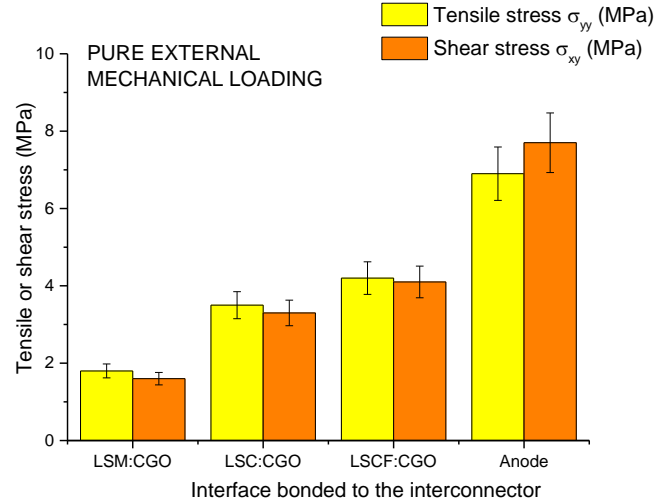

b) 


\section{ACCEPTED MANUSCRIPT}

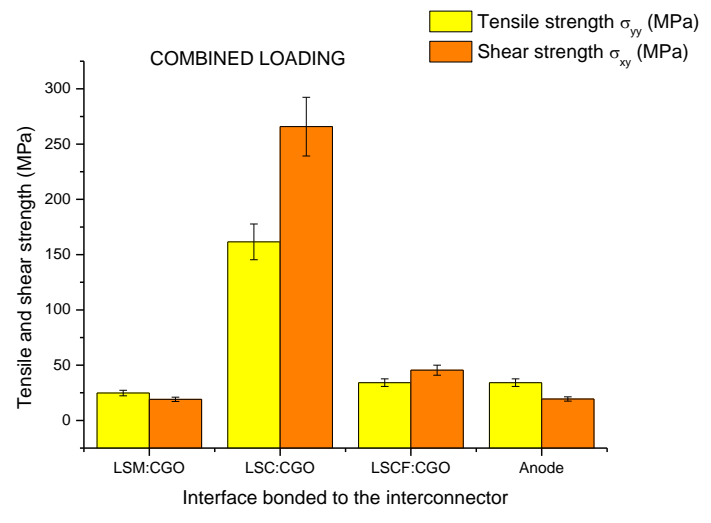

c)

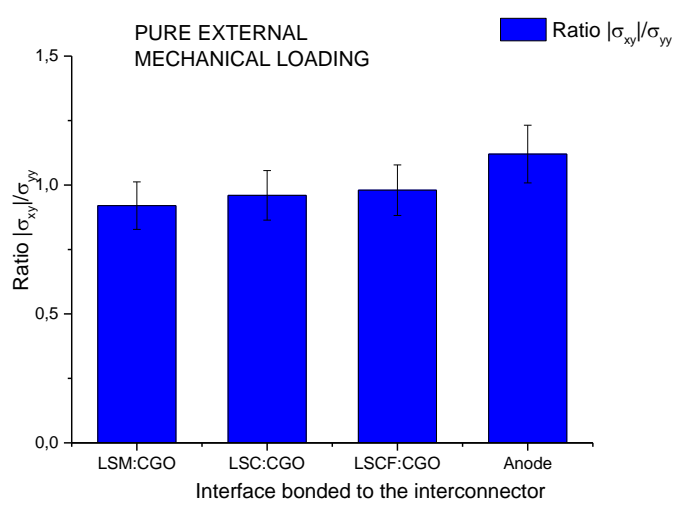

d)

Fig. 3a-c): Average bonding strength of the electrodes-metal interconnect interfaces, d) $\left|\sigma_{x y}\right| / \sigma_{y y}$ ratios for pure external mechanical loading
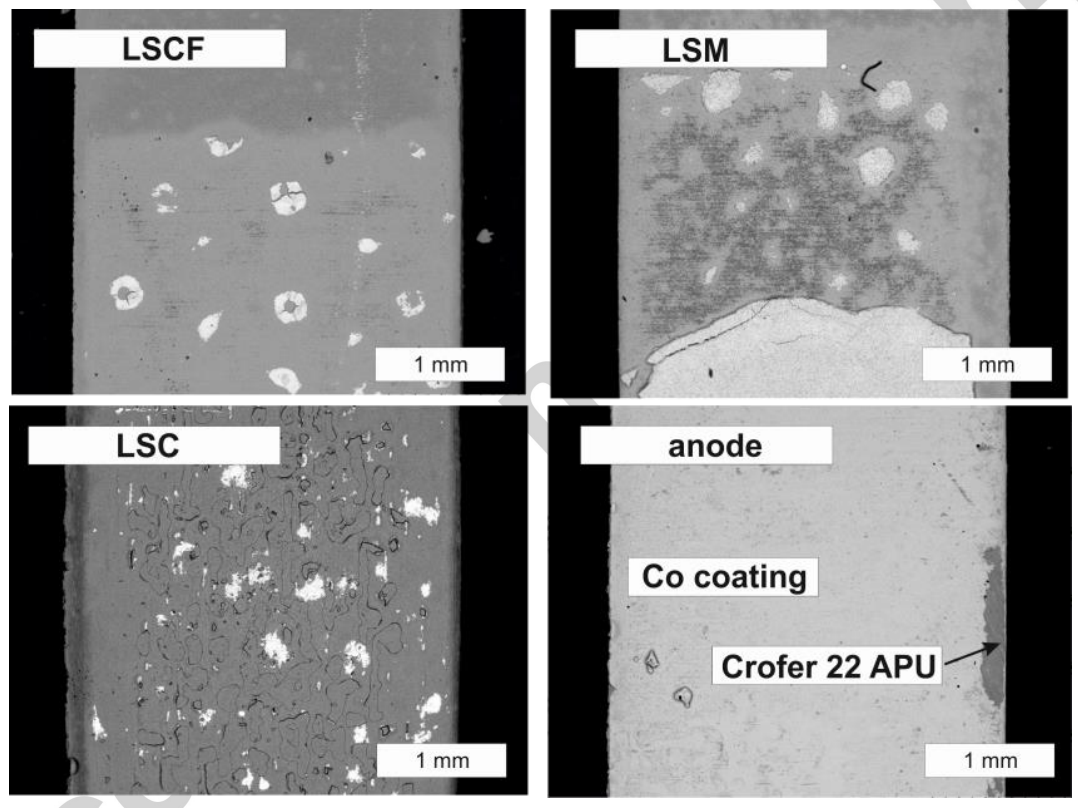

Fig. 4: SEM micrographs of the fresh fracture surfaces on the metal side

\section{Acknowledgements}

Oldrich Sevecek acknowledge a financial support through the project CZ.1.07/2.3.00/30.0005 of Brno University of Technology. Funding from energinet.dk through contract no 2012-1-10747 is gratefully acknowledged.

\section{References}




\section{ACCEPTED MANUSCRIPT}

[1] Park K, Yu S, Bae J, Kim H, Ko Y. Int J Hydrogen Energy 2010;35:8670-7.

[2] Naylor WP. Introduction to Metal-Ceramic Technology, Second Edition. Chicago, London, Berlin, Sao Paulo, Tokyo, Hong Kong 1992:83-113.

[3] Malzbender J. J Eur Ceram Soc 2010;30:3407-13.

[4] Laurencin J, Delette G, Lefebvre-Joud F, Dupeux M. J Eur Ceram Soc 2008;28:1857-69.

[5] Lenz J, Schwarz S, Schwickerath H, Sperner F, Schäfer A. J Appl Biomater 1995;6:55-64.

[6] ISO 9693:1999 - Metal-ceramic dental restorative systems. ISO 96931999

[7] Boccaccini DN. manuscript in preparation. J Power Sources 